\begin{tabular}{|l|l|l||}
\hline \multicolumn{2}{|c|}{ PublisherInfo } \\
\hline \hline PublisherName & $:$ & BioMed Central \\
\hline \hline PublisherLocation & $:$ & London \\
\hline \hline PublisherImprintName & $:$ & BioMed Central \\
\hline \hline
\end{tabular}

\title{
The multiple functions of B cells
}

\begin{tabular}{|l|l|l||}
\hline \multicolumn{2}{|c|}{ ArticleInfo } \\
\hline \hline ArticleID & $:$ & 225 \\
\hline \hline ArticleDOI & $:$ & $10.1186 /$ ar-1999-66759 \\
\hline \hline ArticleCitationID & $:$ & 66759 \\
\hline \hline ArticleSequenceNumber & $:$ & 182 \\
\hline \hline ArticleCategory & $:$ & Paper Report \\
\hline \hline ArticleFirstPage & $:$ & 1 \\
\hline \hline ArticleLastPage & $:$ & 3 \\
\hline \hline & & RegistrationDate : 1999-12-2 \\
\hline ArticleHistory & $:$ & OnlineDate \\
\hline \hline ArticleCopyright & $:$ & Current Science Ltd1999-12-2 \\
\hline \hline ArticleGrants & $:$ & \\
\hline \hline ArticleContext & $:$ & 130753311 \\
\hline \hline
\end{tabular}


Aff1 Charite University Hospital, Berlin, Germany

\section{Keywords}

Autoantigen, autoimmune myocarditis, B cells

\section{Context}

Autoimmune myocarditis is an autoimmune heart disease characterized by inflammatory infiltrates with predominant T-cell-mediated immunopathology. The processes leading to the activation of selfreactive $\mathrm{T}$ cells is hitherto unknown. Myosin immunization is known to induce myocarditis in animal models, whereas presentation of myosin peptides by $\mathrm{B}$ cells to $\mathrm{T}$ cells not tolerized to those epitopes by macrophages and dendritic cells has not been addressed as an essential pathway of the disease. To test the hypothesis that anti-myosin B cells are critical antigen presenting cells (APCs) in autoimmune myocarditis by analysis of the induction of myocarditis in $\mathrm{BALB} / \mathrm{c}$ mice rendered deficient for $\mathrm{B}$ cells by targeted disruption of the immunoglobulin M ( $\operatorname{IgM})$ transmembrane domain (?MT mice), and by treatment with anti-IgM antibodies $(\mathrm{Ab})$ from birth (anti-? mice).

\section{Significant findings}

Backcrossed homozygous mice had no detectable mature B220 ${ }^{+}$B cells in the spleen, but possessed $\mathrm{CD}^{+}$and $\mathrm{CD} 8^{+} \mathrm{T}$ cells. They had little or no detectable $\operatorname{IgM}(<0.2 \mathrm{gg} / \mathrm{ml})$ in their sera. Homozygous mice immunized with cardiac myosin had no antigen $(\mathrm{Ag})$-specific $\mathrm{IgG}$ response. Eight of ten homozygotes immunized with cardiac myosin developed myocarditis with a comparable incidence and severity of myocarditis to those for heterozygous littermates. To

determine whether B cells might be required for Ag presentation when less myosin is available, homozygous and wild-type mice were immunized with 30 ?g of cardiac-myosin. Four of five homozygotes developed myocarditis in contrast to mice immunized with 10 ?g of cardiac myosin.

$\mathrm{BALB} / \mathrm{c}$ mice that were depleted of B cells after birth had no detectable $\mathrm{B} 220^{+}$splenocytes, but still possessed $\mathrm{CD} 4^{+}$and $\mathrm{CD} 8^{+}$T cells. As observed with the ?MT homozygous mice, anti-? mice produced little or no detectable IgM and did not demonstrate cardiac myosin-specific IgG following immunization. All eight 
anti-? mice immunized with cardiac myosin developed myocarditis with a comparable incidence and severity of the disease compared with the wild-type mice.

\section{Comments}

This paper addresses uniquely the role of B cells as APCs in autoimmune myocarditis. Based on controversial data reported by earlier studies the author's conclusions aim to differentiate the function of B cells based on the way the autoantigens are presented, either as tolerogen or as antigen. Since all of the noted previous experiments, including this study, investigated organ-specific autoimmune dieases, it should be differentiated from systemic autoimmunity. In this context, it needs to be emphasized that B cells apparently have a significant role as APCs in systemic autoimmunity as demonstrated more recently (Chan et al, J Exp Med 1999, 189:1639-1648 [abstract]). Another interesting point from the study is the role of the antigen dosage to break tolerance. Although not analyzed in great detail, it provides further evidence that the amount of antigen presented plays a significant role in the induction of autoimmunity.

\section{Methods}

Homozygous and heterozygous ?MT mice, backcrossed to the BALB/c strain for seven to nine generations, were tested. In addition, BALB/c anti-? mice were injected intraperitoneally with 50 ?g of goat anti-mouse IgM Ab, administered five times a week for the first week of life and on alternate days thereafter. Following cardiac myosin immunization, the dosage was increased to 100 ?g of Ab every other day. Normal goat IgG (NGIgG) served as a negative control. B220-, CD4-, and CD8-positive cells in the spleen were analyzed by fluorescence-activated cell sorter (FACS). Subsequently, mouse hearts were analyzed histologically. The diagnosis of myocarditis was according to the Dallas criteria, which established myocarditis as the presence of an inflammatory infiltrate and accompanying myocyte necrosis.

\section{References}

1. Malkiel S, Factor S, Diamond B: Autoimmune myocarditis does not require B cells for antigen presentation. J Immunol. 1999, 163: 5265-5268.

This PDF file was created after publication. 